\title{
Effect of Work Engagement, Job Satisfaction, and Organizational Commitment to Employee Performance
}

\author{
Qodariah, Makruf Akbar, Muchlish Mauluddin
}

\begin{abstract}
The purpose of this research to study the influence of Work Engagement, Job Satisfaction, and Organizational Commitment to Employee Performance PT. (Persero) Surveyor Indonesia. This research uses quantitative approach with path analysis method. The sample of this research is 120 employees of PT. Surveyor Indonesia served as head of department. The results of this study show that; (1) Work engagement directly affects employee performance; (2) job satisfaction has direct effect on work performance; (3) organizational commitment directly affects employee performance; (4) work engagement has a direct effect on organizational commitment; (5) job satisfaction has a direct effect on organizational commitment; (6) work engagement has a direct effect on job satisfaction. Thus the improvement of employee performance can be achieved directly if there is strong influence of work engagement, organizational commitment, and job satisfaction is well developed.
\end{abstract}

\section{Introduction}

In production activities, the government performs its role as an economic actor that is to establish a state company known as State-Owned Enterprises (SOEs). In accordance with Law no. 19 Year 2003, BUMN is a business entity which is wholly or wholly owned by the state through direct participation derived from separated state assets [1-4].

Development as a process of continuous change management in upgrading the welfare and prosperity of the nation, government has a very important role in obtaining these goals. In accordance to Decree No. 19-2002, State Own Enterprise (SOE) may take the form of Travel Bureau, Semi Private Enterprises and Government Enterprises [5-8] In the consumption activity, the government purchases goods and services in order to carry out its duty of providing good service to the community, in the distribution of activities in order to distribute goods that have been produced by state enterprises to the public and as a regulator of economic activity, the government not only play a role as one of the economic actors, but the government also plays a role in planning, guiding, and directing the way the wheels of the economy in order to achieve the goals of national development. Many factors affect one's commitment to the organization, one of which is job satisfaction variable [9-12].

Job satisfaction is an important predictor of organizational commitment. Job satisfaction is an important form of employee attitudes in fostering organizational commitment [13-15].

In addition to influence communication satisfaction and organizational commitment, leadership style also influences organizational performance and behavior "pro social: from employees or called organizational citizenship behavior (OCB). Organizational commitment will foster a sense of cooperation with fellow members of the organization, fellow working groups, respect for helping others. Work Engagement as one of the antecedent variables of organizational commitment has important concepts that affect employee performance and retention. Basically Work Engagement is work oriented, while commitment is oriented towards the organization. Based on the background of the above problem, this study aims to analyze the influence of Work Engagement variables on job satisfaction, organizational commitment and employee performance of PT. Surveyor Indonesia [16-17].

The research/study conducted by Saks for the year 2006 entitled Antecedent and Consequences of Employee Engagement. This study aims to examine the antecedent and consequent models of job and organization engagements as the basis of the theory of social change. The survey was conducted on 102 employees who worked on various jobs and organizations. The results showed that there was a significant difference between job and organization engagements and perceived organizational predicting both job and organization engagements; job characteristics predict job engagement; and procedural justice predicts organization engagements. In addition, job and organization engagements mediated the relationship between antecedents and job satisfaction, organizational commitment, intention to quit, and organizational citizenship behavior (organizational citizenship behavior) [18].

Research / study by Kalkavan, Selma and Katrinli, Alev 2014 entitled "The Effects of Managerial Coaching Behaviors on the Employees' Perception of Job Satisfaction, Organizational Commitment, and Job Performance: Case Study on Insurance Industry in Turkey". This study aims to investigate the effect of managerial direction behavior on job satisfaction, the role clarity, career commitment, work performance and organizational commitment to insurance employees in Turkey. Participants in this study were senior managers with on-line surveys between November 2013 and February 2014. The survey was accessed by 304 people and the number of samples 
used in this study were 229 people [19-20].

\section{Theoretics}

\subsection{Employee Performance}

According to Torrington et al., (2005: 224) "Employee performance is an important element that affects whether or not good organization performance". As also described by Byars and Rue, (2004: 251) that "Performance refers to the degree of accomplishment of the tasks that make up an employee's job". That performance refers to the degree of achievement of tasks that constitute employment work. Performance describes about how well effort done by employees in completing their work. Performance is a good effort made by employees which is a modification of the ability and role (or task) perception. According to Mathis and Jackson, (2011: 156) employee performance can help explain why people want to stay in the company or leave the company. There are three main factors that affect a person's performance:

\section{Individual ability to do the work; \\ 2. Effort expended; \\ 3. And organizational support.}

So performance can be formulated:

Performance $(\mathrm{P})=$ Ability $(\mathrm{A}) \times \operatorname{Effort}(\mathrm{E}) \times \operatorname{Support}(\mathrm{S})$

Such performance measures can be illustrated in Figure 2.1. below this:

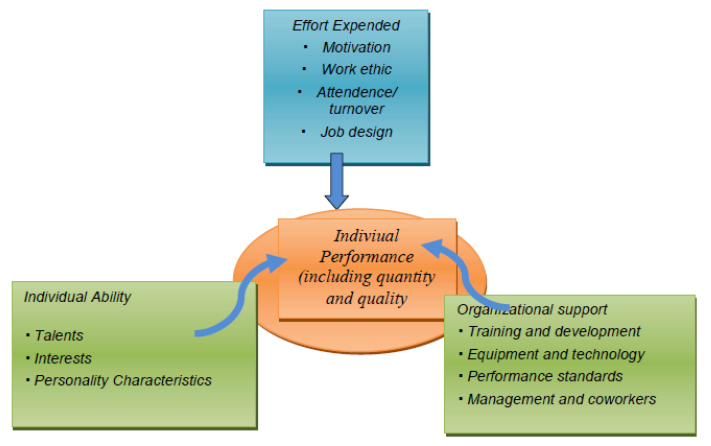

Figure 1 Component of Individual Performance

Source: Mathis, Robert L. and Jackson, John H., Human Resources Management, (USA: Cengage Learning, 2011)

Meanwhile Wirawan, (2013: 732) defines performance etymologically, in his opinion that:Performance stands for kinetics of work energy or performance is the output generated by the functions or dimensions of work or profession performed by human resources or employees within a certain time. From the concept of Wirawan, it is defined that the performance as a form of the ability of members of the organization in accordance with field work which is measured by a certain standard. According to Schermerhonet al., (1991: 59) "Performance is defined formally as the number and quality of tasks solved individually, group or organiza- tionally". The concept shows that the success of the organization and all members of the organization in completing the task both in quality

Revised Manuscript Received on July 05, 2019.

Qodariah,

Lecturer in Faculty of Economis and Business, Universitas Budi Luhur, qodariah.83@gmail.com and quantity. Based on various opinions on the above concepts, it can be synthesized that employee performance is the result that has been achieved by the employee based on the applicable measures to achieve organizational goals, with indicators: absenteeism, tardiness, length of service, dependentable task accomplishment, cooperation, protective acts , constructive ideas, self-training and favorable attitudes.

\subsection{Work Engagement}

Work engagement or worker engagement is a business management concept. In connection with this, Mujiarsih and Jenita, (2012: 1-12) means that:Work engagement or worker engagement is a business management concept which states that employees with high engagement are employees who have full involvement and have high morale in their work as well as in matters relating to the activities of the company in the long run.Meanwhile, according to Schaufeli et al., (2002: 71-92) "engagement as a positive, ful fi lling, workrelated state of mind that is characterized by vigor, dedication, and absorption". That engagement as a positive, emotional and motivational state of mind is characterized by passion, dedication and absorption. Based on the concept of Schaufeli et al. it can be explained that engagement is a force that refers to energetic work, being ambition enough to work hard, even in difficult situations. This dedication is linked to meaningful work experience and dedication in the work signal that the individual prides in his work, finding inspiration. exist within the organizational reward system which, if implemented by an employee, will improve the functioning of the organization.The concept of work engagement by Kahn in Saks, (2006: 600-619) "the harnessing of organization members' selves to their work roles; in engagement, people employ and express themselves physically, cognitively, and emotionally during role performances ". Kahn defines personal involvement as a process that leverages the members of the organization to play a role in their work; involvement, people work and express physically, cognitively, and emotionally directed to show their performance. Richard et al, (2009: 33) for example, Nelsons and Simmons, argues that:Job involvement is a set of work attitudes that bring employees to feel positive emotions for their work to become meaningful individuals, consider their workload to be managed, and have hope about the future of their work.

According to Federman in Nusatria and Suharnomo, (2011: 1-31) that employees with high work engagement are characterized as follows:

1. Focus on completing a job and also on the next job;

2. Feeling yourself is part of a team and something bigger than themselves;

3. Feel capable and do not feel a pressure in making a leap in work;

4. Work with change and approach challenges with adult behavior.

Based on various opinions on the above concept, it can be synthesized that work engagement is the involvement of employees physically, cognitively and emotionally in their work to be more meaningful, with indicators: 
vigor. dedication, and absorption.

\subsection{Job satisfaction}

Keith, (1985: 96) suggests that, "Job satisfaction is the favorablesness or unfavorableness with employees view their work". Job satisfaction is a feeling that supports or does not support experienced employees in the work. Based on the concept of Keith can be explained that job satisfaction relates to a person's feelings that can cause a sense of comfort or discomfort in the work environment that can affect employees in the work. Wexley and Yukl, (1977: 98) define job satisfaction, "is the way an employee feels about his or her job". Job satisfaction is the way employees feel themselves or their work. The concept of Wexley and Yuki is not much different from the concept of Wirawan that is related to the sense and attitude of a person to the job, where the feeling and attitude can be positive or negative.

There are several theories about job satisfaction are well known, among others:

\subsubsection{Discrepancy Theory (Discrepancy Theory)}

The theory of discrepancy is expressed by As'ad, (2001: 105) which states that: Measuring a person's job satisfaction by calculating the difference between what should be and what the perceived reality is. Thus, people will be satisfied if there is no difference between the desired with the perception of reality, because the desired minimum threshold has been fulfilled.

\subsubsection{Equity Theory (Equity Theory)} that:

The theory of equity put forward by As'an which states

People will feel satisfied or dissatisfied, depending on the presence or absence of justice (Equity). Feelings of equity and inequity of a situation, obtained by comparing himself with other people who class, office and elsewhere.Meanwhile, Veithzal Rivai and Ella Jauvani, (2011: 856) states that: If the comparison is deemed fair enough, then the employee will be satisfied. If the comparison is unbalanced but beneficial it can lead to satisfaction, but it can not. But if the comparison is not balanced there will be dissatisfaction.

\section{1) Two Factor Theory (Two Factor Theory)}

The theory of equity put forward by Wexley and Yukl which states that:

Job satisfaction and job dissatisfaction are two different things. Satisfaction and dissatisfaction with work is not a continuous variable. Characteristics of work into two groups of satisfies or motivators and dissatisfies. Satisfies are factors or situations that are the source of job satisfaction consisting of: exciting work, achievement, reward, work itself, responsibility and progress. This factor will cause satisfaction, but the absence of this factor does not always lead to dissatisfaction.

Furthermore, the concept of job satisfaction according to Iverson and Maguire, (2000: 807-839) is "satisfaction with work is considered in the context of the general general attitude towards the employment of the working environment" . Job satisfaction is the attitude of employees to their work as well as their positive or negative assessment of various aspects of the work environment. Based on the concept of Iverson and Maguire can be explained that job satisfaction relates to the attitude of a person to work derived from the work environment.

Based on the above description can be drawn a sentesis that job satisfaction is a positive or negative attitude on the work that will make pleasure or displeasure depending on whether or not the desired needs, with the indicators: the job itself, supervision, co-workers, salary and promotional opportunities.

\section{Organizational Commitment}

Meanwhile, John, et al., (2000: 68-74) defines the following commitments: Commitment as an attitude of close relationship between an employee or an individual with an organization embodied in various forms such as loyalty and the desire to remain because of the inclusion of employees in the organization

According Meyer dan Allen, (1991: 61-89):

Organizational commitment is defined as the individual's "multidimensional psyhological attachment" to his organization. Organizational commitment has two dimensions: 1) it characterizes the employee's relationship in the organization; 2) it has implication for decision to continue or stop membership in the organizational.

Further Meyer, Allen and Smith, (1993: 538 - 551) stated that organizational commitment consists of:

(a) Emotional attachment to the firm (affective): relates to the employee's desire to remain (work in the company) this is an emotional attachment (emotional attachment) or psychological to the organization.

(b) Needs to remain with the firm based upon perceived costs of leaving (continuance): continuation to participate in consistent activities so that the company does not incur any costs incurred by the company and accepted by the individual.

(c) Sense of obligation toward the firm (normative); trust in the acceptance of the goals and values of the organization or the moral obligation to remain firm because of social and organizational rewards.

Meanwhile, according to Luthans, (2001: 235) "organizational commitment is an important dimension for measuring and evaluating employee retention forces in performing tasks with the organization". Based on this concept it can be concluded that the dimension of commitment can be used to measure employee loyalty to the organization. According to Mowdey et al.in Vakola and Nikolaou, (2005: 160-174) "commitment as an attitude that describes the natural relationship between the employee and his organization". Based on this concept, it can be explained that the attachment of each member of the organization to the organization will be built naturally where the organizational goals will be achieved every member of the organization and organization run with a high attachment.

Based on various opinions on the above concept, it can be synthesized that the organization's commitment is an attitude that reflects the loyalty of employees to the 
organization so that there is a strong desire to survive to become members of the organization. The indicators of organizational commitment include: affective commitment, continuous commitment and normative commitment.

The results of the study prove that there is a positive and significant relationship between managerial guidance behavior with satisfaction; there is a positive and significant relationship between the directional behavioral behavior with the role clarity; there is a positive and significant relationship between managerial direction and career commitment; there is a positive and significant relationship between managerial guidance and organizational commitment; there is a positive and significant relationship between managerial guidance behavior and work performance; there is a positive and significant relationship between role clarity with organizational commitment; there is a positive and significant relationship between role clarity with work performance; there is a positive and significant relationship between job satisfaction and career commitment; there is a positive and significant relationship between job satisfaction and organizational commitment; between job satisfaction and work performance has an insignificant relationship; there is a positive and significant relationship between career commitment and work performance; and there is a positive and significant relationship between organizational commitment and work performance.

Research / study conducted by Chughtai, Aamir Ali and Finian Buckley in 2011, entitled "Work Engagement Antecedents, The Mediating Role Of Learning Goal Orientation And Job Performance". This study aims to examine the role of mediation learning goal orientation between Work Engagement variables and two forms of performance that is the role in work performance and innovative work behavior. The samples in this study were 168 respondents from scientists from six research centers in Ireland who were tested using structural equation modeling (SEM) techniques using Lisrel 8.8 software. the results show that trust in supervisor and trust propensity positively and significantly affects work engagement. work engagement affects work performance through the mediation of learning goal orientation variables. Research / study by Albrecht, Simon L. and Manuela Andreetta in 2011 entitled The In fl uence of Empowering Leadership, Empowerment and Engagement on Affective Commitment and Turnover Intentions in Community Health Service Workers "Test of a Model". This study aims to examine the relationship between empowering leadership, empowerment and outcome variables by checking the mediation of engagement engagemen. More specifically, this study tested whether employee engagement mediated the influence of empowering leadership and the empowerment of effective commitment and turnover intention. The study used 139 public health service employee samples. By using Confiigmatory factor analysis (CFA) and structural equations modeling (SEM), the results of the study show that empowerment as a variable mediates the influence of empowering leadership on engagement. Engagement mediates the effect of empowerment variables on affective commitment and Turnover Intentions.

\section{Method}

This research was conducted at PT Surveyor Indonesia (Persero) having address at Graha Surveyor Indonesia, Jl. Gatot Subroto Kav. 56 Jakarta 12950 Indonesia. This research was conducted for 6 (six) months, starting from February until Agustus2015 with activities covering: initial survey, arrangement of research permit, instrument test, validity and reliability test of instrument, data collection, data analysis, and research writing. This study uses a quantitative approach through a structured process. Quantitative approach is applied because with this approach the process of research conducted in a structured and using sample research with a large enough amount that is considered representative of the population ditelitisehingga results obtained in this study is a conclusive result for the population from which the sample research taken. The target population or unit of analysis in this study is a permanent employee of PT Surveyor Indonesia of 424 people. While the focus in this study on the affordable population of PT Surveyor Indonesia employees served as head of department (kabag) of 120 people.

Data analysis techniques use descriptive and inferential statistics. The use of descriptive techniques to obtain a description of the scattering / scoring characteristics of each of the variables studied (data presentation, central size, and dispersion size). Data presentation uses frequency distribution list and histogram. The central size includes mean, median (middle value) and mode. The size of the spread includes the variance and standard deviation. While the inferential analysis is used to test the requirements of analysis (normality test, significance test and linearity test) and hypothesis by using path analysis. The path analysis model as follows:

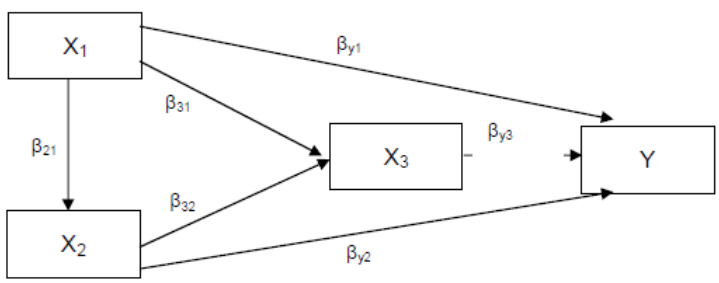

Figure 2 Model of Path analysis

Source: Various literatures that have been processed researchers, 2015

Information:

$\beta X 2 X 1$ : path coefficient of direct influence of work engagement

on job satisfaction

$\beta X 3 X 1$ : path coefficient of direct influence of work engagement

on commitment organizational

$\beta Y X 1$ : path coefficient of direct influence of work engagement

on employee performance

$\beta$ X3X2: path coefficient of direct influence of job satisfaction on

commitment organizational

$\beta Y X 2$ : path coefficient direct influence of job satisfaction on 
employee performance

$\beta Y X 3$ : path coefficient of direct influence of organizational

commitment to performance employees

The path analysis model used in this study can be described in the following structural equations:

$\mathrm{Y}=\beta \mathrm{YX} 1+\beta \mathrm{YX} 2+\beta \mathrm{YX} 3+\varepsilon 2 \ldots \ldots$ (equation 1$)$

$\mathrm{X} 3=\beta \mathrm{X} 3 \mathrm{X} 1+\beta \mathrm{X} 3 \mathrm{X} 2+\varepsilon 1 \ldots \ldots \ldots \ldots .($ equation 2$)$

$\mathrm{X} 2=\beta \mathrm{X} 2 \mathrm{X} 1+\varepsilon 1$ (equation 3 )

Where:

$\mathrm{Y}=$ Employee Performance

$\mathrm{X} 1$ = Work Engagement

X2 = Job Satisfaction

X3 = Organizational Commitment

$\varepsilon 1,2,3=$ Residual variable $/$ error

Based on the research hypothesis, it can be written statistical hypothesis as follows :

1. Hypothesis pertajawork engagement (X1) direct effect on kinerjakarwanwan (Y).

H0: $y 1 \leq 0$

$\mathrm{H} 1: \mathrm{y} 1>0$

2. The second hypothesis: job satisfaction test (X2) has a direct effect on employee performance (Y).

H0: $\mathrm{y} 2 \leq 0$

$\mathrm{H} 1: \mathrm{y} 2>0$

3. The third hypothesis: testing organizational commitment (X3) has a direct effect on employee performance $(\mathrm{Y})$.

$\mathrm{H} 0: \mathrm{y} 3 \leq 0$

H1: $\mathrm{y} 3>0$

4. Fourth hypothesis: job satisfaction test (X2) has direct effect on organizational commitment (X3).

HO: $31<0$

$\mathrm{H} 1: 31>0$

5. The fifth hypothesis: job satisfaction test (X2) has direct effect on organizational commitment (X3).

H0: $32 \leq 0$

H1: $32>0$

6. The sixth hypothesis: testing of engagement work

(X1) has a direct effect on job satisfaction (X2)

$$
\begin{aligned}
& \text { H0: } 21 \leq 0 \\
& \text { H1: } 21>0
\end{aligned}
$$

\section{Result and Discussion}

Based on the calculation of path coefficient on substructural 1, structural sub 2 and structural sub-3, the overall path diagram of $\mathrm{X} 1, \mathrm{X} 2$ and $\mathrm{X} 3$ to $\mathrm{Y}$ variables can be described as follows:

Figure 4 Line Variable Diagrams X1, X2 and X3 to Y

Result of calculation of line coefficient on sub-structural 1, sub structural 2 and structural sub 3 can be summarized and presented in table 4:18 below:

Table 1 Summary of Line Coefficient Calculation Results

\begin{tabular}{|l|l|l|l|l|}
\hline Rute & \multirow{2}{*}{ Coeficien Rute } & $\mathrm{t}_{\text {value }}$ & \multicolumn{2}{|c|}{$\mathrm{t}_{\text {table }}$} \\
\cline { 4 - 5 } & & & $\alpha=0,05$ & $\alpha=0,01$ \\
\hline $\mathrm{p}_{\mathrm{y} 1}$ & 0,383 & 3,448 & 1,673 & 2,004 \\
\hline $\mathrm{p}_{\mathrm{y} 2}$ & 0,322 & 2,854 & 1,673 & 2,004 \\
\hline $\mathrm{p}_{\mathrm{y} 3}$ & 0,202 & 1,774 & 1,673 & 2,004 \\
\hline $\mathrm{p}_{31}$ & 0,229 & 1,740 & 1,673 & 2,004 \\
\hline $\mathrm{p}_{32}$ & 0,285 & 2,168 & 1,673 & 2,004 \\
\hline $\mathrm{p}_{21}$ & 0,284 & 2,152 & 1,673 & 2,004 \\
\hline
\end{tabular}

\subsection{Hypothesis testing}

Hypothesis testing is done to determine the direct and indirect influence between variables. The result of the decision on all hypotheses proposed, described as follows:

\section{First Hypothesis: Work Engagement (X1) Positive Direct Influence on Employee Performance (Y)}

Hypothesis testing to prove that Work Engagement (X1) have direct effect on Employee Performance (Y). The hypothesis tested as follows:

H0: $\mathrm{y} 1 \leq 0$

$\mathrm{H} 1: \mathrm{y} 1>0$

Based on the calculation in Table $4: 15$, the coefficient of $p$ $\mathrm{y} 1$ line is 0,383 with $\mathrm{t}$ count $=3,448$, at $=0,05$ obtained by $\mathrm{t}$ table $=1,673$. By count $=3.448>\mathrm{t}$ table $=1.673$, means $\mathrm{H} 0$ is rejected, the path coefficient is significant. Thus it can be concluded that Work Engagement (X1) has a direct effect on Employee Performance (Y).

2. Second Hypothesis: Job Satisfaction (X2) Positive Direct Influence on Employee Performance (Y).

Testing the hypothesis to prove that Job Satisfaction (X2) has a direct effect on Employee Performance (Y). The hypothesis tested as follows:

H0: $\mathrm{y} 2 \leq 0$

$\mathrm{H} 1: \mathrm{y} 2>0$

Based on the calculation in Table $4: 15$, the value of coefficient path p y2 of 0.322 with $t$ count $=2.854$ at $=0.05$ obtained $\mathrm{t}$ table $=1.673$. Thus $\mathrm{t}$ value $=2.854>\mathrm{t}$ table $=$ 1.673, means $\mathrm{H} 0$ is rejected, then the coefficient of the path signifikan.Dengan can be concluded that Job Satisfaction (X2) directly affect Employee Performance (Y).

3. Third Hypothesis: Organizational Commitment (X3) Positive Direct Influence on Performance of Compound (Y)

Hypothesis testing to prove that Organizational Commitment (X3) has direct effect on Employee Performance (Y). The hypothesis tested as follows: 
H0: $y 3 \leq 0$

H1: $\mathrm{y} 3>0$

Based on the calculation in Table 4:15, the value of coefficient path py 3 of 0.202 with $t$ count $=1.774$, at $=0.05$ obtained $\mathrm{t}$ table $=1.673$. Thus $\mathrm{t}$ value $=1.774>\mathrm{t}$ table $=$ 1.673, means H0 is rejected, then the coefficient of the path signifikan.Dengan can be concluded that Organizational Commitment (X3) directly affect Employee Performance (Y).

\section{Fourth Hypothesis: Work Engagement (X1) Positive Direct Influence to Organizational Commitment (X3)}

Hypothesis testing to prove that Work Engagement (X1) has direct effect on Organizational Commitment (X3). The hypothesis tested as follows:

H0: $31 \leq 0$

H1: $31>0$

Based on the calculation in Table 4:16, the coefficient of $\mathrm{p} 31$ at value 0,229 with $\mathrm{t}$ value $=1.740$, at $=0.05$ obtained $\mathrm{t}$ table $=1.668$. Thus $\mathrm{t}$ value $=1.740>\mathrm{t}$ table $=1.673$, means $\mathrm{HO}$ is rejected, the path coefficient is significant. Thus it can be concluded that the Work Engagement (X1) has a direct positive effect on Organizational Commitment (X3). 5. The Fifth Hypothesis: Job Satisfaction (X2) Positive Direct Influence to Organizational Commitment (X3)

Hypothesis testing to prove that Job Satisfaction (X2) have direct effect on Organizational Commitment (X3). The hypothesis tested as follows:

H0: $32 \leq 0$

H1: $32>0$

Based on the results of calculations in Table 4:16, the coefficient $\mathrm{p} 32$ line value of 0.285 with $\mathrm{t}=2.168$, at $=0.05$ obtained $\mathrm{t}$ table $=1.668$. Thus $\mathrm{t}$ value $=2.168>\mathrm{t}$ table $=$ 1.673, means H0 is rejected, then the path coefficient is significant. Thus it can be concluded that Job Satisfaction (X2) has a direct positive effect on Organizational Commitment (X3).

\section{Sixth Hypothesis: Work Engagemen (X1) Positive Direct Influence to Job Satisfaction (X2).}

Hypothesis testing to prove that Work Engagemen (X1) have a direct effect on Job Satisfaction (X2). The hypothesis tested as follows:

H0: $21 \leq 0$

\section{$\mathrm{H} 1: 21>0$}

Based on the calculation in Table 4:17, the coefficient of p21 is 0.284 with $\mathrm{t}$ count $=2,152$, at $=0,05$ obtained by $\mathrm{t}$ table $=1,668$. Thus $\mathrm{t}$ value $=2.152>\mathrm{t}$ table $=1.673$, means $\mathrm{HO}$ is rejected, the path coefficient is significant. Based on these findings it can be interpreted that Work Engagement (X1) has a direct positive effect on Job Satisfaction (X2).

\section{Discussion}

Based on the results of hypothesis analysis and testing shows that six hypotheses proposed in the research initernyata proven. In detail the discussion of research results and testing of research hypotheses are described as follows:

\section{Work Engagement on Employee Performance}

Based on empirical evidence, the findings of this study indicate that Work Engagement is one of the most important variables and directly affect Employee Performance.

Harter et al (.......). Believes that "there is a relationship between work engagement, customer satisfaction, productivity, profit and employee turnover, which will ultimately lead to increased business success". The condition is in accordance with research in the field which shows that work engagement or employee involvement in PT Surveyor Indonesia is high. The high level of work involvement can improve their performance individually or in groups / teams. In addition, what seems clear is their involvement as a form of employee appreciation of the work by using its ability to achieve company goals. The condition, naturally happens in this company, because almost every involvement in work, they do it focus in completing a job and the next job. Job involvement is strived to be nurtured and continue to be nurtured so that employee performance can be improved in accordance with the expectations of the company.

Based on the calculation of the coefficient of influence of Work Engagement lane on Employee Performance in this research, obtained the result of coefficient of path equal to 0,383 and $\mathrm{t}$ count $=3,448$. at $=0,05$ obtained $\mathrm{t}$ table $=$ 1,673. Bacaue $\mathrm{t}$ value $=3,448>\mathrm{t}$ table $=1,673$, hence significant path coefficient, mean Work Engagement have a direct positive effect on Employee Performance. The results of this study support the theory presented by Harter et al above. The results of this study also support previous research conducted by Chughtai, Aamir Ali and Finian Buckley in 2011 entitled "Work Engagement Antecedents, The Mediating Role of Learning Goal Orientation and Job Performance". The results showed that work engagement affects performance through the mediation of learning goal orientation variables. Based on the above description and empirical verification conducted in this study, it was found that Work Engagement has a direct positive effect on Employee Performance.

\section{Job Satisfaction on Employee Performance}

Based on empirical evidence, the findings of this study indicate that Job Satisfaction is one of the variables needed to support a person's performance, so that the variable is important and has a direct effect on Employee Performance.

Wexley and Yukl (..........) define job satisfaction, " is the way an employee feels about his or her job". Job satisfaction is the way employees feel about themselves or their work. The concept of Wexley and Yukl relates to a person's sense and attitude toward work, where the feelings and attitudes can be positive or negative that will ultimately affect a person's work or performance.

Conditions in the study indicate that employees at PT Suveyor Indonesia seem satisfied to have adequate facilities and allowances, so they show good work and want to stay in the company until retirement (55 years of age). Based on the calculation of the coefficient of influence line Satisfaction Kerjaterhadap Performance Karyawandalam this research, obtained the 
coefficient of the path of 0.322 and $t$ value 2.854. At $=0.05$ obtained $\mathrm{t}$ table $=1.673$. Because $\mathrm{t}$ value $=2.854>\mathrm{t}$ table $=$ 1.673 then the coefficient of significant path, means Satisfaction Satisfaction positive direct impact on Employee Performance. The results of this study support the theory presented by Wexley and Yukl above. Based on the above description and empirical verification conducted in this study, it was found that Satisfaction Satisfaction positive direct impact on Employee Performance.

\section{Organizational Commitment to Employee Performance}

Based on empirical evidence, the findings of this study indicate that Organizational Commitment is one of the most important variables and directly affect Employee Performance. Organizational commitment is needed to improve employee performance. According to Wirawan (.....) that: If the commitment of members of the organization to the organization is high, they will perform their duties maximally and produce high performance. This performance will affect the performance of the organization in achieving its objectives. Commitment will encourage employees who support the company to work more effectively. Employees with high organizational commitment will be work oriented. Employees feel close to the organization as they work and to meet their needs.

In a state-owned enterprise, employee commitment is needed especially to solve various problems that arise so that SOEs can grow and achieve goals. Conditions in the research company that employees have a very high commitment to the company. Conditions in the study show that employees at PT Suveyor Indonesia have high organizational commitments. This is evident from the results of work achievements achieved by each individual and also in a group relationship. The high commitment is possible because the PT. Surveyor Indonesia rewards employees who are committed to the work as well as the organization / company. The awards they receive include precious metals (gold bullion), umroh (after 10 years of service), pilgrimage (after 15 years of service) and other rewards. Based on the calculation of the coefficient of the path of Organizational Commitment to the Performance of Employees in this study, obtained the results of path coefficient of 0.202 and tc $=2.854$. Pada $=0.05$ obtained ttabel $=1.673$. Because $\mathrm{t}=2.854>$ ttable $=1.673$, the path coefficient is significant, it means Organizational Commitment has a direct positive effect on Employee Performance. The results of this research support the theory presented by Wirawan above. Based on the above description and empirical verification conducted in this study, it was found that Organizational Commitment has a direct positive effect on Employee Performance.

\section{Work Engagement of Organizational Commitment}

Based on empirical evidence, the findings of this study indicate that Work Engagement is one of the most important variables and has direct influence on Organizational Commitment. Employees who have work engagement on the organization / company have certain characteristics. According to Federman in Nusatria and Suharnomo that employees with high work engagement are characterized as follows:

1. Focus on completing a job and also on the next job;
2. Feel yourself is part of a team and something bigger than themselves;

3. Feel capable and do not feel a pressure in making a leap in work;

4. Work with change and approach challenges with adult behavior.

Based on that opinion can be explained that employees who have high work engagement will work more than good enough words, they work by committing to goals, using intelligence to make choices how best to complete a task, monitor their behavior to ensure what they do it right and fit the goals to be achieved and will make the decision to correct if necessary.

Conditions at the research site indicate that employees at PT Suveyor Indonesia are engaged in high work or high work angagement. Because they are often involved in various jobs in their respective fields, they feel valued and feel that they are an important part of the company. This will increase their commitment to the company where they work (This is very influential PT Suveyor Indonesia). Based on the calculation of path coefficient of influence of Work Engagement to Organizational Commitment in this research, obtained the result of coefficient of path equal to 0,229 and $\mathrm{t}$ count $=1,740$. at $=0,05$ obtained $\mathrm{t}$ table $=$ 1,673 . Because $\mathrm{t}$ value $=1.740>\mathrm{t}$ table $=1.673$ then the coefficient of significant path, means Work Engagement directly positive effect on Organizational Commitment.

The results of this study support the theory presented by Federmandi above. The results of this study also support previous research conducted by Albrecht, Simon L and Manuela Andreetta". The results of his research indicate that the influence of organizational commitment. Based on the above description and empirical verification conducted in this study, it was found that Work Engagement had a direct positive effect on Organizational Commitment.

\section{Employee Satisfaction Against Organizational Commitment}

Based on empirical evidence, the findings of this study indicate that job satisfaction has a direct positive effect on organizational commitment. Job satisfaction is one of the most important variables and direct influence on Organizational Commitment. According to Farkas and Tetrick that job satisfaction is an important form of employee attitudes in growing organizational commitment. Meanwhile, Reichers stated that there are three factors that influence the emergence of commitment: (a) psychological variables, such as: job satisfaction, identification of organizational values and goals, (b) behavioral variables, such as: attribution, and (c) structural variables, years of service, investment.

Conditions on the ground indicate that employees at PT Suveyor Indonesia seem satisfied or show job satisfaction. It is seen that their performance is increasing and they are increasingly committed to the company where they work. This condition means that the job satisfaction shown by PT Suveyor Indonesia employees has an effect on organizational commitment.

Based on the calculation of path coefficient of influence of Job Satisfaction 
on Organizational Commitment in this research, obtained the results of path coefficient of 0.285 and $t=2.168$. at $=$ 0.05 obtained $\mathrm{t}$ table $=1.673$. Because $\mathrm{t}$ value $=2.168>\mathrm{t}$ table $=1.673$ then the coefficient of significant path, means Job Satisfaction has a direct positive effect on Organizational Commitment. The results of this study support the theory presented by Farkas and Tetrick and Reichers above. Based on the above description and empirical verification conducted in this study, it was found that Satisfaction Satisfaction positive direct impact on Organizational Commitment.

\section{Work Engagement on Job Satisfaction}

Based on empirical evidence, the findings of this study indicate that work engagement is one variable that is very important and direct influence on job satisfaction. Conditions on the ground show that employees at PT Suveyor Indonesia have work engagement or are happy and loyal to the job. The next condition that appears is that they feel satisfied in working or achieving job satisfaction. The condition shows that work engagement has an effect on to job satisfaction of employees at PT Suveyor Indonesia.

Based on the calculation of the coefficient of influence of Work Engagement to Job Satisfaction in this research, the result of coefficient of path equal to 0,284 and $\mathrm{t}$ value $=$ 2,152 . At $=0.05$ obtained $\mathrm{t}$ table $=1.673$. Because $\mathrm{t}$ value $=$ 2.152> $\mathrm{t}$ table $=1.673$, then the coefficient of significant path, means Work Engagement positive direct effect on Job Satisfaction. The results of this study support the theory presented by Saks above. Based on the above description and empirical verification conducted in this study, it was found that Work Engagement had a direct positive effect on Job Satisfaction.

\section{Conclusion}

Based on the analysis that has been done in Chapter V, the findings in this study are as follows:

1. Work engagement has a direct positive effect on employee performance. This means that the higher work engagement then the higher the performance of employees of PT. Surveyor Indonesia.

2. The satisfaction of employment directly positive impact on employee performance. This means that by realizing high job satisfaction, it can improve the performance of employees of PT. Surveyor Indonesia.

3. Organizational commitment has a direct positive effect on employee performance. This means that if the commitment of employees to the organization high, they will carry out their duties to the maximum and will improve performance.

4. Work engagement has a direct positive effect on organizational commitment. This means that the higher the employee's work engagement, the higher the organizational commitment to PT. Surveyor Indonesia.

5. Job satisfaction is a positive direct impact on organizational commitment. This means that by realizing high job satisfaction the employees can increase organizational commitment to PT. Surveyor Indonesia.

6. Work engagement has a direct positive effect on job satisfaction. This means that with the creation of work

engagement or pleasure of employees in work, it will achieve their job satisfaction in PT. Surveyor Indonesia.

Ethical clearance - Not required

\section{Source of funding- Self}

\section{Conflict of Interest - Nil}

\section{References}

[1] Alan M. Saks, Antecedents and consequences of employee engagement, (2006)

[2] Byars Llyod L., and Rue, Lealie W., Resource Management. Seventh Edition, (New York: The McGraw-Hil Companies, (2004).

[3] Davis Keith, Human Behavior at work: Organizational Bahavior (New Delhi: Tata McGraw-Hill Publishing Company, (1985).

[4] Endah Mujiarsih dan Ika Jenita Ratnaningsih, "Meningkatkan Work Engagement Melalui Gaya Kepemimpinan Transformasional dan Budaya Organisasi", Artikel eprint.unisbank.ac.id, (2012).

[5] Freud Luthans Organizational Behavior, Ninth Edition. Boston: McGraw Hill,(2001).

[6] JohnP Meyer,.Allen Natalie J., "Three Component Conceptualization of Organiza-tional Commitment",Human Resource Management Review, (1991).

[7] John P Meyer,.Allen Natalie J. \& Smith C.A, "Commitment to Organizations abd Occupations: Extension and Test of a Three Component Conceptualization", (1993).

[8] John R.Schermerhon, James G. Hunt and Osborn Richard N, Managing Organizational Behavior. Fourth ed. (New York:John Wiley and Son, Inc, (1991).

[9] K.E. John L., Mark C., Duhan Dale F., Howell Roy D. \& Wiekes Robert W. "An Integrated Model of Sales Manages Communications Practices", Journal of The Academy of Marketing Scince, (2000).

[10] Maria Vakola dan Ioannis NikolaouAttitudes Toward Organiza-tional Change. What The Role of Employees' Stress and Commitment", ,(2005).

[11] Mathis, Robert L., and Jackson, John H., Human Resources Management, (USA: Cengage Learning, (2011).

[12] Michael A.Richard, William G. Emener, dan Willian S. Hutchison, Jr., Employee Assistance Programs: Wellness/Enhancement Programming (Illinois :Charles C Thomas Publisher, Ltd, (2009).

[13] Moh. As'ad, Psikologi Industri. Edisi Keempat, Yogyakarta: Liberty, (2001).

[14] R.D.Iverson dan Maguire, C., "The Relationship Between Job And Life Satisfaction: Evidence From A Remote Mining Community", Human Relations, (2000).

[15] Sandi Nusatria dan Suharnomo, Employee Engagement : Anteseden dan KonsekuensiStudi pada Unit CS PT. Telkom Indonesia Semarang, Artikel. repository.undip.ac.id, (2011).

[16] Torrington, Derek; Laura Hall and Stephen Taylor, Human resources Management. Sixth Edition. New York: Prentice Hall, (2005).

[17] Veithzal Rivai dan Ella Jauvani S., Manajemen Sumber Daya Manusia untuk Perusahaan (Jakarta: P.T. Rajagrafindo Persada, (2011).

[18] W.B Schaufeli, Salanova, M., Gonzalez-Roma, V. and Bakker, A.B., "The Measurement of Engagement and Burnout: A Two Sample Confirmatory Factor Analytic Approach”, 2002.

[19] Wexley, K.N and G.A Yukl, Organizational Bahavior and Personnel Psychology. (Home Wood. Illionis: Richard D. Irwin, 1977.

[20] Wirawan, Kepemimpinan "Teori, Psikologi, Perilaku Organisasi, Aplikasi dan Penelitian”, Jakarta: RajaGrafindo Persada, (2013). 